Article

\title{
RACISM AS A WORKLOAD AND BARGAINING ISSUE
}

\section{BY RITA KAUR DHAMOON}

\begin{abstract}
My main contention is that racism should be read beyond the registers of attitude, discrimination, human rights, or harassment - rather, I approach racism as a workload issue that labour organizations and employers need to address at the level of collective bargaining. To explore this argument, I focus on racism and workload as it relates to Black faculty, faculty of colour, and Indigenous faculty in universities and colleges in Canada, although the argument can be applied to other job types and other places. While there is significant research on racism in universities, it remains largely disconnected from the literature on workload in universities. Many unions have policies and statements in support of local, national and international anti-racist struggles, but the idea of racism as a workload issue has not been seriously taken up by unions/associations, or for that matter by anti-racist activists on university/college campuses. I offer reasons why racism is a workload issue, and consider the potential role of unions in addressing racism.
\end{abstract}

\section{Keywords} bargaining

Racism; unions; workload; faculty of colour; Indigenous faculty; collective

On June 2, 2019 Shelby McPhee, a Black graduate student was racially profiled while attending the Federation for the Humanities and Social Sciences annual conference in Vancouver. In support of Shelby, the Black Canadian Studies Association, Black women, non-Black Muslim women and other women of colour mobilized to call out anti-Black racism; time and energy was taken to write letters, develop and distribute statements of support, and provide witness accounts of the incident. The next day, June 3, at the same conference, after the Government of Canada released the national inquiry into murdered and missing Indigenous women and girls final report and named this violence as genocide, Indigenous women and 2SLGBTQQ people undertook the work of media communications, supporting Indigenous families, responding to questions on the report at panels that were unrelated to violence against Indigenous women and girls. In both instances, the labour of Indigenous women, Black peoples, and women of colour was necessary to respond during the academic gathering, but for how many of us is this type of work recognized and compensated by universities? My central premise is that racism is an issue of workload and not just a matter of discrimination, harassment or human rights, and should be addressed as such 
by employers and labour organizations for Indigenous peoples, Black people and people of colour (IBPOC).

In November 2015, the Canadian Association of University Teachers (CAUT) passed a policy that recognized the increased workload of academic staff members in equality seeking groups, which they state includes, but is not limited to, racialized persons, women, Aboriginal peoples, 2SLGBTQQ, and persons with disabilities. It is worth citing the policy in its entirety:

Academic Staff members represent the same diversity and experience the same racism and discrimination as populations in the broader society. Academic staff who are also members of equity-seeking group are frequently called upon to perform extra duties, such as interpreting documents through an "equity lens," providing liaison with community groups, mentoring and advising, providing media contact, writing reports that address equity concerns, serving on committees, and finding and contacting people who work in the area of equity in higher education. Members of equity-seeking groups are often called on to conduct research for up-to-date information about equity in higher education, even when it is not within their area of academic research. Requests for additional work come not only from a variety of administrative and departmental sources, but also from academic staff associations. Such work receives little official recognition and adds an unfair burden to the workload of members of equity-seeking groups, thus creating another equity problem.

Additional work, including work on equity issues, performed by members of equity-seeking groups is an academic contribution and should be taken into consideration when applications for tenure or promotion are assessed and in every process based on evaluation of a file (for example for internal research grants, requests for sabbatical leave, etc.). When such work is undertaken over and above normal remunerated duties, the academic staff member should be compensated.

Despite this commitment, the CAUT policy has yet to filter down to universities. Moreover, it is not clear what actions are required to address the workload of academic staff members in equityseeking groups.

Certainly, equity is recognized as a workplace issue. In Canada, workplace discrimination, harassment, and unfair practices workplace are covered under the Canadian Human Rights Act, the Employment Equity Act, and the Canada Labour Code. As well, there is a rich body of work on racism in employment and labour markets (e.g. Galabuzi 2006, 2018; Khattab 2012; Nangwaya, 2011, 2016). In addition, there is an established literature specifically on race and universities which has critically addressed issues of teaching and learning, the language of 'diversity', human rights, multicultural and/or anti-racist pedagogy, Indigenizing the academy, postcolonial knowledge, and experiences of women of colour and Indigenous women in the academy (such as 
Alfred 2007; Ahmed, B. 2008; Carty 1991; Ford 2011; Godlewska, Moore and Bednasek 2010; Harris 2012; Henry and Tator 2012; Kovach 2009; Mihesuah and Wilson 2004; Sian 2019; Smith 2012; Rodriguez, Gonzales-Howell, and Anesi 2012; Turner, Gonzalez, and Wood 2008). But typically, racism is treated as a matter of equity or discrimination rather than an issue of workload.

University teachers' unions and associations in Anglo-American contexts are certainly well aware of increasing workloads. In the UK, the University and College Union (UCU) has an extensive campaign on workload, and following a national survey released a report entitled 'Workload is an education issue' (UCU 2016). The report highlights that faculty in both higher education and further education sectors are working on average more than two days unpaid every week; that workload is unmanageable and unsustainable for the majority of academic staff and lecturers; that faculty are taking on more responsibility and administration; and that professional and career development is suffering as a result of increasing workload pressure. Without a doubt, the UCU is an innovator in developing tools to track workload, and yet, the 2016 report says nothing about racism as a workload issue, despite the fact that racism is endemic in British universities (Sian 2019). It may be the case that in general UK unions lead the way on establishing internal mechanisms for the self-representation of oppressed groups; such vehicles help develop consciousness of group concerns, confidence and skills, and an infrastructure to formulate policies (Colgan and Ledwith 2002; Gumbrell-McCormick and Hyman 2013). Britain also a history of autonomous anti-racist union action since the 1960s, such as the Pakistani Workers Union. But, as Colgan and Ledwith $(2002,162)$ note, self-organization "does not operate in a vacuum and in itself does not guarantee achievement of the oppressed social group's aims."

Similarily, the American Association of University Professors has published articles on what faculty unions can learn from workload policies of universities. They have also reviewed the findings of the National Study of Postsecondary Faculty (NSPF), which reports that, over the past two decades, full-time faculty members report working an average of 53.3 hours per week, in comparison to 37.5 hours for the typical US full-time worker (Benedict and Benedict, n.d.). And yet, much like the UK context, racism is not taken up as a workload issue. Likewise, the National Tertiary Education Union (NTEU) in Australia recognizes that workload is an issue that can be addressed by caps on teaching hours, a percentage breakdown of academic work, and implementing procedures for dealing with workload disputes. But the specificities of racism as a workload issue are unaddressed. The NTEU does recognize the importance of short amount of paid, and sometimes unpaid, leave for members of an Aboriginal or Torres Strait Islander community to participate in important cultural activities or responsibilities; but even this leave is framed as a cultural accommodation, rather than a matter about the division of labour.

In short, racism and workload are treated as two separate and distinct domains of academic life, both by university as employers and unions as worker organizations. The idea of racism as a workload issue has not been seriously taken up by unions/associations, or for that matter by antiracist activists on university campuses. My focus here is on IBPOC in universities and colleges in Canada, but I recognize that some similar issues apply for non-academic staff in universities and 
colleges, for jobs beyond the academy, and for contexts beyond Canada. ${ }^{1}$ My goal in this paper is to examine racism in universities at the register of workload, and not just the conventional registers of discrimination, equity, human rights, or harassment in the workplace.

My contention is that 'racism' and 'workload' are inseparable for faculty of colour and Indigenous faculty, whether they are permanent or temporary. As such, workers, union and association leaders/negotiators, faculty, and administrators in universities need to integrate racism and oppression as a workload issue that has implications for collective bargaining and faculty agreements/contracts. This is not because of some business case for racial equity, as a 2013 W.K. Kellogg Foundation report declared, where it is argued that more minority purchasing power (e.g. minority home ownership) and reducing racialized income inequities would inject trillions of dollars into the economy. Such a business argument falsely presumes that: ontologically, the division of labour can be equalized in a capitalist economy; equal opportunity to free markets will erase racism; and that the business economy is not always and already colonizing, gendered, ableist, homophobic, and transphobic. Instead, my argument is that racism has implications for the division and distribution of labour for IBPOC faculty, with real material impacts that should be of concern to all workers and to those who represent faculty interests.

\section{Defining our terms}

\section{Racism}

Augie Fleras (2014) notes that racism is critically approached through five overlapping frames: racism as biology, in which intelligence and morality are thought to be determined by fixed genetic and/or phenotypical differences; racism as ideology, in which humans are organized hierarchically into distinct and discrete categories based on ideals about physical, cultural, and psychological life; racism as culture whereby perceptions based on what people do and how they practice their religion and culture are anchored in discourses of national unity, identity, and citizenship; racism as structure whereby oppression is regularized by virtue of being in systemically embedded in normative fabric of society; and racism as power whereby authority and coercion is monopolized and abused by ruling classes, and nonwhites are disciplined through willful coercion as well banal practices and acts that routinize white privilege (Fleras 2014, 27-53).

Further, there are many kinds of racism such that white supremacy does not take on just one formation; instead, there is anti-Black racism, Islamaphobia, Orientalism, anti-Asian racism, settler racism, different kinds of colonialism (e.g. franchise colonialism, settler colonialism, oceanic colonialism). Racism is also not the same as colonialism; in the case of North America, Australia, and New Zealand racial violences are ongoing conditions of colonialism, in which people, land, and relations of life are translated through capital relations and remade through patriarchal white sovereignty and possessive (Moreton-Robinson 2004). Racism is also not a stand-alone category

\footnotetext{
${ }^{1}$ For example, following an anti-apartheid approach, the National Union of Metal Workers of South Africa adopts, as one of its key principles, a commitment to breaking down racial work designations.
} 
or axis of oppression, for it is constituted by and constituting of other modalities of dominance and resistance, whereby each system of oppression and privilege needs the others in order to function (Arvin, Tuck and Morrill 2013; Collins 1990; Crenshaw 1994).

\section{Workload}

'Workload' tends to be classified as quantitative (the amount of work to be done) and/or qualitative (the difficulty of the work). There are particular kinds of work that designated social groups do, as feminists have long shown with regard to household work. While for all faculty it may seem that we face mostly cognitive workload issues because so much of our work is about thinking, processing, articulating, disseminating knowledge and information, I start from the premise that cognitive work encompasses the physical and material, especially in terms of concentration; sitting at computers for hours; standing during lectures; missing meals because of meetings; travelling to conferences and workshops; investing time for work tasks over family and relationships; changing sleep patterns and losing sleep so as to meet work deadlines; holding workrelated tension in our bodies; walking across campus carrying a heavy pile of papers/exams to mark etc.

The distribution of workload for faculty varies across universities, but in general research institutions tend to have a split of $40 \%$ research, $40 \%$ teaching, $20 \%$ service; and teaching institutions have some variation of all three with much higher percentages dedicated to teaching (typically somewhere between 60-80\%). Faculty workload is designated through departmental standards, written and unwritten expectations, and collective agreement clauses on appointments, duties and responsibilities, evaluation of members (annual reviews, merit pay, and student evaluations), tenure and promotion, study leaves/sabbaticals, professional development, contract work/sessional agreements, sick leave and long-term disability, and compassionate leave.

Despite all of these clauses, policies, and practices, workload issues for faculty are severely under-addressed by unions and associations, perhaps not least because they are already under attack in this neoliberal age. One of the major challenges is the representation of sessional faculty/part-time instructors/contract faculty/non-permanent faculty (including graduate students) over workload. The rise of non-permanent faculty in universities in many countries, including Canada and the U.S., raises serious concern about the contingent nature of faculty employment that makes it precarious to raise issues about inadequate working conditions, the low salaries paid for work that is equivalent or sometimes more than permanent faculty, job insecurity for these faculty members; this precarity for non-permanent faculty exists to give more financial security for departments and universities by exploiting a cheap, fluctuating, and exploitable workforce (MacDonald 2013). ${ }^{2}$ And yet it also creates more uncertainty for teachers, especially

\footnotetext{
${ }^{2}$ As noted by Leo Charbonneau (2014) in University Affairs, data on sessional faculty is frustratingly scant. The precarious nature of the casualization of the academic workforce has been made worse by neo-liberal policies of universities, which have led to exploitation, increased uncertainty about employment, lack of support, and lack of career progression.
} 
temporary faculty who are women, a non-binary gender, those with non-western accents, those wearing overtly religious symbols, or those disabled - namely those that deviate from the norm.

In addition, as Michael Hurley and Sam Gindin (2015) note, "the relentless intensification of every-day work life rarely surfaces as a union priority." The problem, according to Hurley and Gindin, is that too many unions have had to trade the goal of limiting capitalist power for gains over the price of labour power, namely wages and benefits, while simultaneously legislatively banning or restricting the right to withhold labour, and undermining worker militancy by fostering individualized consumption and integrating the moderate working-class into state sponsored programs that allowed for the spread of home ownership (such as through lower interest rates). Despite the gains made by unions and association, universities have demanded "in the name of competitiveness and restoring the profits that are the lifeblood of a capitalist economy, a lowering of both material expectations and intensified workloads."3

\section{Why is racism a workload issue?}

While the distribution of work and workload on the whole needs to be more fully addressed by unions/associations and universities, workload issues are distinct for faculty of colour and Indigenous faculty because of racist and colonizing discourses. This may well be obvious to IBPOC faculty, but it is clearly not obvious to those representing workers in universities and colleges, otherwise it would be raised at bargaining tables. This is despite the connections made by Black radical intellectuals on 'racial capitalism' (such as Cox 1948; Robinson 1983), as well as Black feminists, Indigenous feminists, and other critical race scholars (such as Day 2016; Kuokkanen 2011; Lorde 1984; Maynard 2017) who have also been critical of the connections between race, capital, and gender. And yet, capital and race still tend to be treated as isolated, silo issues.

Workload issues arising from racism and colonialism are mostly treated as independent of collective bargaining by faculty associations and faculty unions; most universities and collective agreements position racism as a matter of equal opportunity/discrimination/human rights/harassment. While, or maybe because, equity and human rights offices across university campuses have had their budgets and staff slashed, and most have very little actual institutional power now, matters of race and racism tend to be relegated and contained to these institutional units. Almost all universities have equity, discrimination, and harassment policies and procedures, and some sort of general proclamation in their mission statements, annual reports, and strategic plans about diversity (Ahmed, B. 2008; Ahmed, S. 2012, 2013). Most university collective agreements between labour and employer tend to typically include one or two sections that

\footnotetext{
${ }^{3}$ As well as calling for workloads to be addressed by bargaining, Hurley and Gindin (2015) make a compelling case for also going beyond bargaining so that workers focus not only on what they need as union/association members but also on broader class issues such as healthcare provision and expansion of social services that they need/may need outside of their workplace. In short, even unions and associations which are meant to represent worker interests do not adequately address workload issues.
} 
reference equal opportunity, discrimination, and equality, or some such clause. In other words, while universities and unions/associations certainly aim/claim to promote workplace social justice, the principles of anti-racism are NOT the basis of union-worker-employer relations. This is not to say union/association representatives and negotiators are not committed to these ideas, but that contract talks and other union-management interactions are typically approached as if they are race-free.

Racism is a workload issue for faculty of colour and Indigenous faculty because i) it changes the distribution of labor from that undertaken by white faculty; and ii) it is work that is not accounted for in initial appointment discussions/letters of offer, revised individual agreements, faculty-university agreements, and departmental standards and responsibilities, pay scales, the distribution of labour, and unwritten practices. While white faculty who take an anti-racist approach in their pedagogy and institutional practices may well have to deal with racist incidences, this burden is overwhelming carried by faculty of colour and Indigenous faculty. White faculty also have a choice of stepping away that is not usually available to nonwhite faculty (even if we do not always know how to respond or know what to say); and racism is not inscribed on white bodies in the same way that it is on IBPOC faculty.

This additional and intensified labour comes in the form of preparing for and responding to various kinds of everyday and institutional racism, addressing and confronting racism and colonialism, and supporting others who experience racism and colonialism. All of this currently unrecognized work takes away from time and energy that universities dictate should be spent on research, teaching, and service. Sometimes racism comes at the expense of completing work that is recognized by universities, but it is predominantly dealt with in addition to the explicit expectations of the job. Some examples of the kind of labour that IBPOC faculty often have to adopt, consciously undertake, or have imposed on them include:

Teaching

- Heavier teaching loads compared to white faculty for service courses such as introductory courses and required courses.

- Whether or not course material touches on racism and colonialism, the faculty member often has to spend time explaining why they qualified to teach a course, especially if they have a nonwestern accent, wear overt nonwestern symbols, have not yet completed their Ph.D. or do not have a Ph.D. but other kinds of knowledge expertise (e.g. community-based knowledge) - not just once at the beginning of a course, but often repeatedly during a course.

- There are also assumptions that Indigenous faculty can and should teach courses on Indigenous content, South Asian faculty teach courses on India or diasporas, Black faculty know the entire field of race and Black studies, even when this is not their area of training or interest. On these occasions, the labour of learning these fields of study, especially for temporary faculty in need of work, falls on them. The same expectations do not exist for white faculty, whether they are permanent or not. 
- Expending time and also energy seeking extra materials, videos, statistics, reports, and other data on racism and colonialism that students will find valid and credible, or justifying why non-traditional academic sources are important and relevant.

- Additional preparation for lectures/seminars/department meetings/faculty meetings following racist comments/action by students or faculty colleagues. For women of colour, Indigenous women, trans and queer non-white women, this is not separate from preparing and bracing for sexist, misogynist, homophobic, and transphobic encounters.

- If teaching material that is not on issues of race and colonialism, continuously justify their legitimacy as knowledgeable teachers.

- Rewrite lectures because a class was derailed by racism and colonialism, and needs to be addressed differently than initially prepared.

- Casual/temporary nonwhite faculty and Indigenous faculty have to prepare for uncertainty in the classroom because their pedagogy is ranked lower than that of permanent faculty. They also have to navigate the erosion of workers' rights, and the flexibilization and casualization of work contracts (Lopes and Angeli-Dewan 2014/2015).

- IBPOC faculty spend inordinate amounts of time preparing new courses that conceptually and pedagogically interrupt white heteropatriarchy. They may or may not have the opportunity to teach those courses a second or third time, especially if in temporary positions. They are therefore always in a process of innovation that is only exploited and never rewarded.

- Sessional gendered-racialized teaching staff are hyper-surveilled and harassed by technologies, such as online student evaluations.

\section{Service}

- Indigenous faculty take on the additional labour of building relations with local Indigenous community members on behalf of their institutions; developing new programs and/or extending existing programs in line with strategic priorities on integrating Indigenous issues; vetting applications from Indigenous students; responding to internal documents and reports; disproportionately supervising Indigenous students and non-native students who focus on studies concerning Indigenous peoples.

- Mentoring Black students, students of colour and Indigenous students not in their classes, but who need support navigating the white sexist masculinities of the neoliberal colonizing academy.

- Undertake administrative positions with little infrastructure support compared to white colleagues.

- Be the token equity representative on multiple department, faculty, university committees.

- Write sections of departmental/faculty/university reports, marketing material, and program reviews related to Indigenizing the academy equity, race, and diversity. 
- Do additional research and preparation for agenda items on hiring practices, and other university policies and practices that may be related to strategic priorities related to Indigenous programming, internationalization, and equity.

- For some Indigenous peoples, learn about and engage with local Indigenous peoples from other nations so as to enable their institution to learn the appropriate protocols when interacting.

\section{Research}

- Get trained and/or independently train in the marginalized scholarly literature as well as the mainstreams of conventional disciplines.

- Justify research program that is based on one's own racialized community or experiences.

- Document tenure and promotion wars that contain systemic barriers of discrimination.

- For some Indigenous peoples, attend ceremonies of other Indigenous nations and travel to their traditional lands for ceremonies, conduct research, build relations.

- The cost of racial profiling when travelling or crossing borders to attend conferences and workshops, a requirement of our jobs.

In addition, there is miscellaneous work, or work that does not fit easily into the triad of teachingservice-research. Harney and Moten (2013, 26-30) might call this 'fugitive/renegade/castaway work' in the undercommons of the university, whereby the subversive intellectual cannot be entirely banished and yet remains unwelcome, subject to scrutiny under the guise of teaching observations, canonical reading lists, inclusion and diversity etc. In institutional-speak, this might be legible as 'institutional cultural work'.

Miscellaneous work/fugitive work/institutional cultural work

- The collective labour of spending hours debriefing with other Black people, people of colour and Indigenous peoples about a racist and/or colonial encounter you had, or that they had in the workplace- often with students as well as faculty colleagues.

- If a high-profile scholar-activist, undertake extra work to respond to public racist attacks against them or the cause/members of the group they are advocating for (e.g. Black faculty speaking up about Black Lives Matter, Indigenous faculty criticizing pipeline projects, nonwhite scholars critical of Israeli policies targeting Palestinians). Such attacks include calls for resignation and discipline, withdrawal of institutional funding, personal threats to safety.

- Shopping and packing own food to take to campus because the racism of campus cafeterias or faculty lounges is unbearable.

- Set-up, find funding, and run autonomous groups, networks, listservs, workshops etc. specifically to address issues facing the diverse interests of IBPOC. 
For cis-females, lesbian, queer, trans and gender non-conforming women of colour and Indigenous faculty in the academy, especially if in precarious temporary contract, sessional, or untenured positions - who are often "presumed incompetent," (Gutierrez et. al. 2012) "seen but not heard," (Luther et. al. 2001), and still small in numbers and presence (Kobayashi 2009; Monture 2009) - the forms of labour can specifically include:

- Teaching courses that are unpopular or difficult to teach, often without teaching assistant support, and with the consequence of not being able to teach in areas that tapped into their particular knowledge or interests (Luther et. al 2001).

- Creating new courses that include Indigenous and critical race women-centered, feminist, queer content; or provide others with relevant race-related and Indigenous sources to include in their courses.

- Serving as the native informant, whereby Indigenous women and women of colour help white people in the academy negotiate their way through the 'alien' culture (Razack 2001).

- Avoiding/navigating/unpacking/assimilating into the divide-and-conquer strategies that arises when there is more than one person of colour and Indigenous person within a department of mostly white people.

- Navigating chilly climates in departments and universities (Carty 1991; Chilly Climate Collective 1995; Marchak 1996); this can be at the physical and affective level of walking through corridors filled with sexist-homophobic-racist colleagues; at the institutional level of discussions on programming and course offerings; at the social level of conference dinners, department retreats, in line-ups at campus cafeterias; and at the epistemological level of knowledge production.

- Providing emotional labour to students, white colleagues, and male colleagues of colour and who are Indigenous (Chan et. al. 2014). For example, if teaching material on racism and colonialism, provide emotional support to white students who feel guilty about their whiteness.

- Taking on additional financial cost and planning in what to wear so as to refuse racist stereotypes (of the Black mammy, the submissive Japanese teacher, the backward Muslim woman, the incompetent Latina with an accent, the native Indian princess etc.) in order to hold creditability and legitimacy amongst colleagues and students.

- Spending time and energy on how best to hold their bodies in professionalized settings that are informed by Eurocentric standards of racist-sexist-gender conforming bodies. This may involve fragmenting or concealing parts of their bodily self (Ford 2011).

- Providing care in the form of affective and institutional support for other marginalized colleagues, both publicly (e.g. at department meetings) and privately (e.g. debriefing after another racist encounter) in ways that are physically depleting and potentially institutionally risky.

- Spending time to read journal and book manuscripts of other marginalized faculty as well as marginalized students who are not in their program, in order to offer comments and feedback 
so as to identify red flags that may lead to 'reject' by potential publishers because of criticisms of colonialism and racism.

- Doing menial tasks, such as writing program proposal documents, writing annual reviews, taking on tedious administrative tasks.

- Navigating feminist spaces that fail to address racisms and colonialisms.

The distribution of work varies for different nonwhite faculty. As an article on racism in the education system by an organization called 'Working While Black in Nova Scotia' states, those of African descent face a particular set of burdens that reflect the colonial and racist context of Nova Scotia and Canada. Some examples include:

Black teachers can be subtly expected to be the ones to deal with "problem" black students, even if they're not in their class. This means they have a higher workload since they already have their own students to deal with.

Black teachers are expected to be the ones to organize events like African heritage Month assemblies, or to lead cultural groups for black students. It's complicated because often black teachers want to be good role models and help create positive experiences for kids from the black community, but at the same time the expectation is stifling when your workload is heavy. Also, it's great when a black teacher teaches a course like African Canadian Studies, but also that expectation can be stifling. Maybe a black teacher would rather teach another course...

When you're the only black teacher in a school people always turn to you and ask "well, what do you think about that?" whenever an issue of race is discussed. As if all black people have the same opinions and the one black person in the room always wants to be the spokesperson. White people need to think: do they think they could speak on behalf of all white people if the situation were reversed? (WWB 2015)

Such additional and/or intensified labour is largely not integrated into university work expectations or faculty union/association agreements.

For some people of colour and Indigenous peoples, the years and instances of racism accumulate, such that eventually they develop serious health problems (Vakalahi and Starks 2011), intergenerational trauma (Sullivan 2013), and post-traumatic stress disorder especially from being exposed to repetitive acts of racism (Just Jasmine 2016). Sometimes racism requires the need to take sick leave, often justifying it on a more medicalized basis (such as high blood pressure, heart problems, insomnia) because racism is not seen as a legitimate ground for sick leave, or because it is too exposing and precarious-making for the faculty member having to take such a leave. For IBPOC faculty, their research or teaching can be adversely affected but they nonetheless meet or 
exceed the standards of research and teaching at the expense of personal health and/or relations; some pull back on doing anti-racist and anti-colonial work, especially if they are criticized by Chairs or Deans for this work and their job/tenure/promotion is made risky because of this criticism; others have to transition to other departments or universities to get away from racist colleagues and demands even as they carry the legacy of racism; and yet others leave university life permanently, often with adverse material and mental health effects. There is a cost to racism - to the individual and the people they share their lives with, other members of groups affected, and also to universities who fail to address racism. Racism is a public health issue that exists within universities as it does throughout society (HPHR 2016).

\section{Addressing racism as a workload issue: the limits and possibilities of labour organizations}

There is now a rich body of scholarly and non-scholarly work that outlines ways to make transformation in the academy to address racism, specifically by providing structural and financial support for professional organizations, changing institutional procedures and policies, creating more hospital environments (Ford 2011, 474), integrating and mainstreaming Indigenous knowledge and methodologies, decolonizing education, hiring more people of colour and Indigenous peoples, and advocating for mentoring programs. But the question arises: can faculty unions and associations be agents of change with regards to racism and workload? I focus my attention here on labour organizations rather than universities and colleges as employers because it is the job of unions and worker associations to represent the interests of their members. And, in contrast to employers, labour is more likely to tackle these issues directly at the bargaining table.

There are several good reasons to be wary and suspicious of universities and faculty unions/associations as agents and sites of anti-racist and anti-colonial change. First, in AngloAmerican contexts, universities and worker organizations have developed with monocultural ideological assumptions and practices rooted in colonizing practices. All universities in North America are literally built on Indigenous lands; as such, the only possible relationship to the university today may be a criminal one, as Harney and Moten $(2013,26)$ suggest, in which permission to build institutions was never asked or granted by Indigenous peoples. Indeed, even the 'critical' academic seeks/requires/necessitates recognition by the university even while "the university is site of social reproduction of conquest denial" (Harney and Moten 2013, 32, 40). Dorothy Smith states:

Universities in Canada were founded in and were integrated with the ruling apparatus of imperial powers that were implicated in the genocidal treatment of the peoples native to the territory we call Canada, institutions of slavery, the subjugation of other civilizations...Skin colour becomes the present trace of membership in a formerly subjugated people in the context of intellectual and cultural traditions founded in imperialism (Smith 2002). 
One example of the imperialist underpinning of higher education institutions in Canada is the founding of McGill University in 1821 by James McGill. ${ }^{4}$ On the 'About McGill' website of McGill University, James McGill is described as a trader, pioneer, and philanthropist. His "determination to create a rigorous system of education" seems to overshadow the fact that as a colonial settler, business man, education advocate, volunteer Colonel with the Montreal militia, city magistrate, and elected member of the Legislative Assembly for Lower Canada, he was also a slave owner and a key player in French-English battles over possessing Indigenous lands, specifically through his business interests as a fur trader and as a land owner. It was through his access and control over Indigenous lands and Black slaved bodies that he made his wealth. He left substantial funds to the Royal Institution for the Advancement of Learning after his death, a bequest that not only funded McGill University but also helped fund the University of British Columbia (which was known as McGill University College of British Columbia until 1915), the University of Victoria (an affiliated college of McGill until 1916), and Dawson College (which began as a satellite campus of McGill). In other words, higher education in Canada was founded on elite white interests and the bodies of Black and Indigenous peoples so as to advance ruling British and French interests. In light of such histories, unions have become better at including Indigenous peoples within their structures, but also have a history of pushing out Indigenous wage workers in favour of non-Indigenous wage workers (Fernandez and Silver 2017). Moreover, colonialism is not a historical event but an ongoing set of processes and structure with the underlying logic of expanding settler sovereignty over Indigenous sovereignities, and consolidating global capitalism through white possession (Moreton-Robinson 2004).

Second, unions have a long history of being racist and colonial (Leah 1990). In the early 1900s, Anti-Asian riots in Vancouver, Canada, San Francisco, Bellingham, and Washington along the North American west coast were directly led by labour unions as well as small businesses (Sugimoto 1973). The White-only Canadian Brotherhood of Railway Employees, which was formed in 1908, pushed railway employers to establish Jim Crow practices up until the mid-1950s, and worked with the Canadian Congress of Labour and the Department of Labour after WWI to institute segregation as an official national practice in railways (Nangwaya 2016). To counter racism by employers and unions, unions in Canada were set up specifically for Afrikan car-porters workers in 1917, Chinese railroad workers in 1916, Chinese shingles workers in 1919, and Chinese cooks and restaurant workers in 1920 (Mathieu 2010; Nangwaya 2016).

Racism within worker organizations remains prevalent today. For example, in 2016, after public outcry over racial carding by police officers in Ontario and documents provided to the mayors of Brampton and Mississauga by the Peel Coalition Against Racialized Discrimination about racism, a South Asian turbaned man, Amrik Ahluwalia, was given the position of the Peel Police Services Board Chair with the mandate to make racial reform. He was one of many who condemned the practice of racial carding. Not long after he began as Chair, the Peel Police Senior Officers Association - which represents senior ranks between inspector and staff superintendent,

\footnotetext{
${ }^{4}$ My thanks to Roshni Narain for drawing McGill's racist history to my attention.
} 
and some civilian managers - called for Ahluwalia's resignation after he pushed for sweeping reforms, criticized Chief Jennifer Evans for ignoring a Board vote to stop street checks/racial carding, and called for an independent equity and diversity audit. The audacity of a man of colour to confront racism angered members of the senior officers' association that they issued a formal public letter to the residents of Peel calling for Ahluwalia's resignation. This was on the heels of a similar letter written by the Peel Regional Police Association president Paul Black that claims that the board, by calling for a review of the force's hiring and promotions practices through an equitydiversity lens, "endorsed the narrative that labels our members racist" (Grewal 2016a, 2016b). In other words, members of unions and associations deny they are practicing racism and respond with racist claims when challenged.

Third, even when unions/associations may sign onto anti-harassment and equity policies, they often lack any internal procedures for dealing with racism, sexism, and homophobia enacted by executive members and union/association representatives. Moreover, as Nangwaya (2016) has shown, through the electoral process and machinery, elected and appointed positions, staff jobs and constituency groups, and affirmative action or equity structures, white-dominated worker organizations seek to domesticate or co-opt some unionists of colour and Indigenous unionists. While compliant union activists of colour and Indigenous activists are rewarded within unions, those enacting "principled, anti-racist opposition" are given "the big stick across the back." Nangwaya's study of race and unions shows that "In spite of trade unions' anti-racist resolutions, anti-racist policy documents, workshops on racism and equity, and equality statements read at union meetings, white supremacy is still blocking the full participation of racialized members" (2016, n.p).

Finally, like most institutions, universities and unions/worker associations tend to prefer mainstream 'diversity' discourses over direct confrontations against racialized and colonizing power. Sara Ahmed (2009, 2012, 2013) has empirically documented how decades of 'doing diversity' has done little to change institutionalized white privilege, and instead enables what she calls non-performativity. She tracks how diversity work depletes the energy of practioners to do diversity work by having them write about diversity instead; and depletes energy to do radical work while rewarding those who support institutional agendas of "happy-talk" and assimilation. In addition, there is clearly a failure of all institutions to address racisms and colonialisms that operationalize through and extend interlocking forces of sexism, disableism, capitalism, homophobia, and transphobia. While these intersections of oppression form and shape all institutions, they are almost entirely ignored or seemingly foreign to institutional policies on equity and diversity, such that universities and unions/associations only deal with one ground of discrimination. When examined together at all, they tend to be treated sequentially (for example, racism first, then sexism or vice versa) or added to one another (for example, women and persons with disabilities each experience discrimination, and women with disabilities have compounded discrimination), rather than interwoven (OHRC 2001).

In light of these limitations of unions/associations and universities, why turn to them at all to address racism as a workload issue? While remaining skeptical of unions/associations and 
universities because they are places and agents of punishment and discipline for many people of colour and Indigenous peoples, they also carry institutional power to negotiate protection and compensation for workers. In the current era of corporatization of higher education, association/union representation has the potential to address the uneven distribution of work that arises from racism and colonialism.

As a starting point, I propose that racism-as-a-workload issue could be addressed in the following ways through union/association activities, whether that be through collective bargaining, representing individual members, advocating on internal committees and university committees, advising members, or making policy changes:

- Compensate Indigenous faculty assigned additional formal work (e.g. sitting on Dean advisory committees) and 'informal work' (building relations with local Indigenous communities) to develop, expand, and implement strategic initiatives and policies.

- Draw upon lessons from the UK practice of instituting internal mechanisms in unions for the self-representation of oppressed groups, but with the additional infrastructure to guarantee that their voices are heard at the upper levels (e.g. voting rights on certain committees, core funding).

- For unions to campaign for legislative reform that provides for stronger protections of working conditions for IBPOC.

- Collect data for bargaining purposes. For example, over several years, track workloads of all faculty and compare white faculty, faculty of colour, Black faculty, and Indigenous faculty, in terms of actual hours worked, allocation of duties, workload increases, pace and intensity of work. Integrate a breakdown according to gender, dis/ability, national origins, university status, age.

- Instead of pathologized as an individual problem that warrants sick leave, have a section in collective agreements on taking a paid leave of absence because of racism and colonialism if the person chooses, so that such absences can be tracked and approached as a constitutive factor at work.

- Financially and institutionally compensate faculty for the division and distribution of work that is done in teaching, research, and service work that arises from racism and colonialism. This may seem difficult to track, but universities are in the business of measuring and quantifying. Compensation could be provided in the form of salary, time-off, adjusted designation of duties, an allowance for additional duties, amendments in the tenure and promotion expectations. There is a risk that IBPOC may be seen as doing less work, but universities already adjust workload for some kind of labour (for example, reduce teaching load while serving as departmental graduate director or Chair).

- Financially and institutionally compensate for the division and distribution of work that is done under the miscellaneous/fugitive/institutional cultural work. Additional compensation for those IBPOC faculty in temporary positions. 
- Have merit pay for IBPOC faculity who teach topics on race, anti-racism, colonialism, and whiteness that are deemed politically, emotionally, and institutionally charged.

- Enable compassionate leave to take care of family and/or friends experiencing various modes of racism and colonialism.

- Expand recognized teaching and service work to include the support provided by IBPOC faculty to other marginalized colleagues and students not under their supervision or in their classes.

- Train more white faculty to undertake anti-racism work, especially on whiteness, white privilege, and white supremacy.

- Recognize that the demographics and context of an institution will change the workload for specific social groups (for example, a university with only a few Black faculty may lead to disproportionate work done by those faculty members to support the growing number of international Black students; or a university seeking to expand its Indigenous programing will encompass more care-work by Indigenous women in support of male Indigenous faculty and Indigenous students).

- Hire more BIPOC faculty (Sian 2019), with the understanding that more BIPOC faculty is not the same as equitable work distribution.

These are some potential avenues. But if such practices are adopted, they need to be approached without further burdening IBPOC faculty and staff.

\section{Conclusion}

Ultimately, turning to union/associations may be a case of using the master's tools, false consciousness, or pragmatism. Or perhaps the institutional failure to recognize the additional work of Indigenous faculty, Black faculty, and faculty of colour is preferable because if universities were to institutionally recognize the additional labour, they would likely claim this as a diversity success story; and as Sara Ahmed warns, universities are highly skilled at appropriating discourses of antiracism via 'diversity' in their own service. At the same time, because racism affects the division and distribution of work, it needs to be taken seriously by union/association representatives as a priority labour issue.

\section{Acknowledgements}

I am indebted to Roshni Narain and Fairn Herising for reading earlier drafts of this paper and providing great feedback, and also to Amal Rana and Heidi Kiiwetinepinesiik Stark for the many conversations about racism and workload. I continue to learn from you all. Special thanks to the anonymous reviewers whose excellent questions, insights, and directions for revisions helped me to much improve the paper. All the limitations and errors are mine. 


\section{References}

Ahmed, Bipasha. 2008. "Teaching critical psychology of 'race' issues: Problems in Promoting antiracist practice." Journal of Community \& Applied Social Psychology, 18: 54-67

Ahmed, Sara. 2009. "Embodying diversity: problems and paradoxes for Black feminists." Race, Ethnicity and Education 12 (1): 41-52.

Ahmed, Sara. 2012. On Being Included: Racism and Diversity in Institutional Life. Durham: Duke University Press;

Ahmed, Sara. 2013. "Doing Diversity Work in Higher Education in Australia," Educational Philosophy and Theory 38 (6): 745-768.

Alfred, Taiaiake. 2007. "Indigenizing the Academy? An Argument Against." Academic Matters, February 22-23.

Arvin, Maile, Eve Tuck and Angie Morrill. 2013. "Decolonizing Feminism: Challenging Connections between Settler Colonialism and Heteropatriarchy," Feminist Formations, 25 (1): 8-34.

Benedict, Mary Ellen and Louis Benedict. N.D. "What Faculty Unions can learn from workload policy in Ohio," American Association of University Professors https://www.aaup.org/article/what-faculty-unions-can-learn-workload-policyohio\#.XRJ3IdNKjL8

Carty, Linda. 1991. "Black women in Academia: A Statement from the Periphery. In Bannerji Himani, L. Carty, K. Delhi, S. Heald and K. McKenna Unsettling Relations: The University as a Site of Feminist Struggle. Toronto: Women's Press, 6-15.

CAUT, Canadian Association of University Teachers. 2015. "Recognition of Increased Workload of Academic Staff Members in Equity-Seeking Groups in a Minority Context.” Available at: http://www.caut.ca/about-us/caut-policy/lists/caut-policy-statements/recognition-ofincreased-workload-of-academic-staff-members-in-equity-seeking-groups-in-a$\underline{\text { minority-context. }}$ 
Chan, Adrienne, Rita Kaur Dhamoon and Lisa Moy. 2014. "Metaphoric Representations Of Women of Colour in the Academy: Teaching Race, Disrupting Power." borderlands e -journal 13 (2): n.p.

Charbonneau, L. 2014. "Sessional Instructors: what we know so far.” University Affairs, July 16. Available at: http://www.universityaffairs.ca/opinion/margin-notes/sessional-instructorswhat-we-know-so-far/.

Chilly Climate Collective. 1995. Breaking Anonymity: Chilly Climate for Women Faculty. Waterloo, Ontario: Wilfred Laurier University Press;

Colgan, Fiona and Sue Ledwith. 2002. "Gender, diversity, and mobilisation in UK trade unions," in Fiona Colgan and Sue Ledwith (eds). Gender, Diversity and Trade Unions: International Perspectives. London and New York: Routledge, 154-185.

Collins, Patricia Hill. 1990. Black Feminist Thought: Knowledge, Consciousness and the Politics of Empowerment. New York and London: Routledge.

Cox, Oliver C. 1948. Caste, Class, and Race. New York: Monthly Review.

Crenshaw, Kimberle. 1994. Mapping the margins: Intersectionality, identity politics, and violence against women of colour. In The public nature of private violence, ed. M. A. Fineman and R. Mykitiul, 93-120. New York: Routledge.

Day, Iyko. 2016. Alien Capital: Asian Racialization and the Logic of Settler Colonial Capitalism. Duke University Press.

Fleras, Augies. 2014. Racisms in a Multicultural Canada: Paradoxes, Politics, and Resistance. Waterloo: Wilfred Laurier University.

Fernandez, Lynne and Jim Silver. 2017. Indigenous Peoples, Wage Labour and Trade Unions: The Historical Experience in Canada. Winnipeg: CCPA.

Ford, Kristie A. 2011. "Race, Gender and Bodily (Mis) Recognition: Faculty Experiences with White Students in the College Classroom." The Journal of Higher Education 82 (4): 444478.

Galabuzi, Grace-Edward. 2006. Canada's Economic Apartheid: The Social Exclusion of Racialized Groups in the New Century. Toronto: Canadian Scholars Press Inc., 2006. 
Galabuzi, Grace-Edward. 2018. "The Colour of Poverty: Racialization and Inequality in Canada," in Racism and Anti-Racism in Canada edited by David Este, Liza Lorenzetti, and Christa Sato. Halifax: Fernwood Press.

Godlewska Anne, Jackie Moore and C. Drew Bednasek. 2010. “Cultivating Ignorance of Aboriginal Realities.” The Canadian Geographer, 54 (4): 417-440;

Grewal, San. 2016a. Peel senior police officers call on board chair to resign. The Toronto Star. June 27, 2016. https://www.thestar.com/news/gta/2016/06/27/peel-senior-police-officers-callon-board-chair-to-resign.html;

Grewal, San. 2016b. Peel cops' letter claims board deems them racist. The Toronto Star, July 2, https://www.thestar.com/news/gta/2016/07/02/peel-cops-letter-claims-board-deemsthem-racist.html.

Gumbrell-McCormick R. and R. Hyman. 2013. Trade Unions in western Europe: Hard Times, Hard Choices, Oxford: Oxford University Press.

Gutierrez M, G., Niemann Y.F, Gonzalez C.G., and Harris A.P, eds. 2012. Presumed Incompetent: The Intersections of Race and Class for Women in Academia. Boulder, Colorado: University of Colorado Press.

Harney, Stefano and Fred Moten. 2013. The Undercommons: Fugitive Planning \& Black Study. Wivenhoe, New York: Minor Compositions.

Harris, Tina M. 2012. "Black Feminist Thought and Cultural Contracts." New Directions for Teaching and Learning, 10: 55-64

Henry, Francis \& Carol Tator, eds. 2012. Racism in the Canadian University: Demanding Social Justice, Inclusion, and Equity. Toronto: University of Toronto.

HPHR. 2016. "Racism is a Public Health Problem," http://harvardpublichealthreview.org/hphreditorial-racism-is-a-public-health-problem/.

Hurley, Michael and Sam Gindin. 2015. "Work Overload: Time for a Union Strategy." Canadian Dimension, September 13, https://canadiandimension.com/articles/view/work-overloadtime-for-a-union-strategy, n.p. 
Just Jasmine (2016) Self Care for People of Colour After Psychological Trauma. JustJasmine blog post, July 6 2016, http://justjasmineblog.com/self-care-for-people-of-color-afteremotional-and-psychological-trauma/.

Khattab, Nabil. 2012. "Winners' and 'losers': the impact of education, ethnicity and gender on Muslims in the British Labour Market," Labour market diversity and differences 26(4): 556573.

Kobayashi, Audrey. 2009. "Now You See Them, How You See Them: Women of Colour in Canadian Academia," edited by Frances Henry and Carol Tator, In Racism in the Canadian University: Demanding Social Justice, Inclusion, and Equity. Toronto: University of Toronto Press, 60-75.

Kovach, Margaret. 2009. Indigenous Methodologies: Characteristics, Conversations and Contexts. Toronto: University of Toronto Press.

Kuokkanen, Rauna. 2011. 'From Indigenous Economies to Market-Based Self-Governance: A Feminist Political Economy Analysis'. Canadian Journal of Political Science 44 (2): 275-297.

Leah, Ronnie. 1990. Linking the struggles: racism, feminism, and the union movement. Kingston, Ontario: Industrial Relations Centre, Queens University.

Lopes, Ana and Indra Angeli-Dewan. 2014/2015. "Precarious Pedagogies? The Impact of Casual and Zero-Hour Contracts in Higher Education." Journal of Feminist Scholarship 7/8: 2842.

Lorde, Audre. 1984. Sister Outsider: Essays and Speeches. Freedom, CA: Crossing Press.

Luther, Rashmi, Elizabeth Whitmore and Bernice Moreau eds. 2001. Seen but not Heard: Aboriginal Women and Women of Colour in the Academy. Ottawa: Canadian Research Institute for the Advancement of Women.

MacDonald, M. 2013. "Sessionals, up close." University Affairs, January 9, http://www.universityaffairs.ca/features/feature-article/sessionals-up-close/.

Marchak, Patricia. 1996. Racism, Sexism, and the University: The Political Science Affair at the University of British Columbia. Montreal and Kingston: McGill University Press. 
Mathieu, Sarah-Jane. 2010. North of the Color Line: Migration and Black Resistance in Canada, 1870-1955. Chapel-Hill, North Carolina: The University of North Carolina Press.

Maynard, Robyn. 2017. Policing Black Lives. Halifax: Fernwood Publishing.

Mihesuah, Devon Abbott and Angela Cavender Wilson. 2004. Indigenizing the Academy: Transforming Scholarship and Empowering Communities. University of Nebraska Press.

Monture, Patricia. 2009. "Doing Academia Differently: Confronting 'Whiteness' in the University," edited by Frances Henry and Carol Tator, In Racism in the Canadian University: Demanding Social Justice, Inclusion, and Equity. Toronto: University of Toronto Press, 76-105.

Moreton-Robinson, Aileen. 2004. "The possessive logic of patriarchal white sovereignty: the High Court and the Yorta Yorta decision,” borderlands 3(2): n.p.

Nangwaya, Ajamu. 2016. 27 January. “How Trade Unions Co-opt Anti-Racism Resistance.” Share, http://sharenews.com/how-trade-unions-co-opt-anti-racism-resistance/.

OHRC, Ontario Human Rights Commission. 2001. An Intersectional Approach to Discrimination: Addressing Multiple Grounds in Human Rights Claims. Toronto: OHRC.

Sian, Katy Pal. 2019. Navigating Institutional Racism in British Universities. Palgrave MacMillan.

Smith, Dorothy. 2002. "Regulation or Dialogue.” In Kahn S and Pavlich D, eds. Academic Freedom and the Inclusive University. Vancouver: University of British Columbia Press.

Smith, Linda. 2012. Decolonizing Methodologies: Research and Indigenous Peoples. London: Zed Books, 2nd edition.

Sugimoto, H. H. 1973. “The Vancouver Riot and its International Significance." The Pacific Northwest Quarterly 64(4): 163-174.

Sullivan, Shannon. 2013. "Inheriting Racist Disparities in Health: Epigenetics and the Transgenerational Effects of White Racism. Critical Philosophy of Race 1 (2): 190-218.

Razack, Sherene. 2001. "Racialized Immigrant Women as Native Informants in the Academy”. In Rashmi Luther, Elizabeth Whitmore, and Bernice Moreau eds. Seen but not Heard: 
Aboriginal Women and Women of Colour in the Academy. Ottawa: Canadian Research Institute for the Advancement of Women, 57-68.

Robinson, Cedric J. 1983. Black Marxism: The Making of the Black Radical Tradition. Chapel Hill: University of North Carolina Press.

Rodriguez Dalia, Afua O’Boahene, Nicole Gonzales-Howell, and Juliann Anesi. 2012. "Practicing Liberatory Pedagogy: Women of Color in College Classrooms." Cultural Studies: Critical Methodologies 12 (2): 96-108;

Turner, Caroline S., Juan Carlos Gonzalez, J. Luke Wood. 2008. "Faculty of colour in academe: What 20 years of literature tells us.” Journal of Diversity in Higher Education 1(3): 139-168.

UCU. 2016. Workload is an education issue: UCU Workload survey report 2016. London: University and College Union

Vakalahi, Halaevalu F. Ofahengaue and Sandra Hardin Starks. 2011. "Health, Well-being, and Women of Colour Academics." International Journal of Humanities and Social Science 1(2): 182-190.

WWB, Working While Black in Nova Scotia (2015) Racism in the Education System. http://www.workingwhileblackns.com/2015/04/10/racism-in-the-education-system/. 